Guest Editorial, part of a Special Feature on Global Water Governance: Challenges and Future Scope

\title{
Editorial on Global Water Governance
}

\author{
Joyeeta Gupta $^{1,2}$ and Claudia Pahl-Wostl ${ }^{3}$
}

Key Words: governance processes; governance scenarios; water ethics; water governance; water law

In the aftermath of the Earth Summit 2012, it becomes critical to ask-Are our global governance institutions designed in a manner that they can promote converging policies at the national level to address a range of new, different, and fast emerging environmental, water, and social problems as a consequence of the increasing pace of industrialization, urbanization, and globalization? In particular, what types of problems should they be addressing and how can the institutional architecture be improved in order to enhance problem solving?

One specific challenge for global governance is the issue of water resources. Are water challenges a global challenge, and as such, do they require governance at a global level? Whereas some years ago the political discourses favored local management through to management at the river basin level, this debate is now theoretical as it has been overtaken by the reality of attempts at global water governance (in addition to governance efforts at other administrative levels). The question to be posed is rather (a) which specific water challenges require governance at the global level and why, and (b) does the emerging incrementally developing global governance landscape have the institutional architecture to deal with the wide range of water challenges that are affecting the global community? The literature on the current state of global water governance concludes that global water governance reflects conflicts of values and science, and has a diffuse and fragmented character with heterogeneous players working towards competing goals without any clear indications of emerging global leadership (Castro 2007, Dellapenna and Gupta 2008, 2009, Pahl-Wostl et al. 2008, Huitema and Meijerink 2009, Gupta et al. 2010, Gupta and Lebel 2010, Hoekstra 2011). Global water law is highly pluralistic in nature. Global financial resources being dedicated to water management are being channeled in specific directions that are not complemented by a global legitimate and democratic decision-making process.

While the present global governance framework does quite well in terms of information generation and sharing, agenda setting, and creating multiple forums for discussion, it does not do quite as well in terms of promoting regulatory frameworks that link discourses and scientific evidence to binding agreements. Since there is an ad hoc evolving global governance system, an increasingly important and legitimate question for scientific inquiry is - Can a study of the organic growth of governance systems and their partial inability to deal with current water problems with a speed and effectiveness commensurate with the nature of the problems help assess the strengths and weaknesses of the system? Can it offer ideas for improving existing governance frameworks and help identify scenarios to try to steer the political process in specific directions?

Against this background, this Special Feature on Global Water Governance: Challenges and Future Scope aims to elaborate on six key governance questions: (a) What are the challenges for governance science from the perspective of policymakers? (b) What is the role of ethics and values in global water governance? (c) What does an evaluation of the evolution of specific water governance coordination mechanisms tell us about the processes of governance and the missing links in governance? (d) What are the formal governance options, which are most popular, why, and what are their strengths and weaknesses? To what extent is UNWater able to coordinate water governance issues at the UN level and deal with global water governance challenges? (e) What are the prospects for global water governance in dealing with global water challenges in the 21 st century? And a synthesis paper aims to bring all the critical issues together and address the issue, (f) What are the challenges for global water governance, and how can the various theoretical and policy contributions to this Special Feature be put into perspective to derive insights on the future of global water governance?

This Special Feature uses a common definitional framework to start with. Based on the existing literature, this Special Feature sees governance as the exercise of authority, by different social actors in a society, through the development and implementation of explicit and implicit substantive and procedural rules to manage resources for the social good (Rosenau 1992, 2000, Commission on Global Governance 1995, Doornbos 2001, Kahler and Lake 2003).

Governance generally involves all social actors in society and almost all activities that they engage in, in terms of creating awareness and mobilizing other actors. However, only a small part of the governance spectrum has the authority and legitimacy to make regulatory decisions. At the same time,

\footnotetext{
${ }^{1}$ Department of Geography, Planning and International Development Studies, Amsterdam Institute of Social Science Research, University of Amsterdam, ${ }^{2}$ UNESCO-IHE Institute for Water Education, Delft, ${ }^{3}$ University of Osnabrueck, Germany
} 
there are other actors who have resources and initiative and can lead to actual decision-making and implementation at ground level. The disconnect between those who have the resources and are willing to invest it in specific directions and those who have regulatory authority and legitimacy but lack the resources is particularly evident in the water governance field. This will be an issue that we will be reflecting on.

In terms of theoretical approaches, we use a range of disciplines (ethics, international relations and law, water sciences), concepts (value systems, scale, institutions, governance), and theories such as science-policy integration, fragmentation, and pluralism (developed in the legal literature), complexity theory (developed in systems analysis), and regime analysis and earth system governance (developed in international relations theory). Conceptual diversity is required to do justice to the complexity and richness of the issues to be explored.

The first article brings together a series of policy-makers from governmental to nongovernmental bodies, and argues that there is a conflict between treating water as a "sector" and treating it as a cross-cutting issue, and that depending on how one frames water, one may come up with different governance options (Gupta et al. 2013). It also argues that at the global level, the coordination of water issues is primarily "light" in character; however, this does not imply that there needs to be a strong coordination mechanism. It submits that hybrid governance involves a whole range of actors but may not necessarily bring "formal" legitimacy that may trigger action. The problems at the global level probably reflect the variety of gaps (funding, capacity, policy, administrative, information, accountability, and objective) that can be found at the national level. The role of global-level actors in influencing national policy is also not uncontroversial. This analysis leads to a series of research questions that are seen as policy relevant.

Governance inevitably incorporates trade-offs between differing values. Groenfeldt and Schmidt (2013) argue that whether one takes a management, institutional capacity, or social-ecological systems approach, each approach embodies its own value system. The authors then argue for unpackaging the value system embodied in differing approaches to governance, reasoning about these values, and then moving from a values-based approach to developing ideas about governance. As the global level increasingly influences water policy at multiple levels of governance, the question of the normative underpinnings of global policy become ever more important.

Clarity about the normative underpinnings could emerge from the global web of water governance. While the 1997 UN Watercourses Convention gives some ideas of the major values that have become legal principles, there is no specific water organization at the UN level that could play a role here.
Coordination bodies have been established as an efficient way to bring together the collective wisdom of the UN agencies. Schubert and Gupta (2013) argue that the different coordination bodies are designed not to tread on existing turfs but that their very "lightness" of touch pre-empts their ability to become coordinating and steering agencies. Baumgartner and Pahl-Wostl (2013) argue that UN-Water, which coordinates water issues within the UN, essentially functions as a bridge between the experts and the political arena.

In addition to the issue of coordination, processes are critical to the generation of consensus. Pahl-Wostl et al. (2013) argue that the vacuum in formal governance processes has led to ad hoc processes being developed to deal with various issues. However, many of these processes are characterized by missing links; these missing links could partially explain why global water governance is less effective. This analysis is based on case studies of the story of access to water and sanitation, the large dam controversy, and the links between climate change and water governance.

The question that arises is in which direction is global water governance heading. Dellapenna et al. (2013) examine four water governance options in the light of existing scenarios of future water worlds. They conclude that given the seriousness of possible water challenges in the multiple water futures, there is a need for structural solutions, also at the global level. They make a strong case for promoting an umbrella legal agreement that protects water values. They argue that strong narratives can mobilize social networks and movements to demand change.

This Special Feature ends with a review of the literature that focuses on the need for, form of, and challenges facing, global water governance. It argues that the drivers of water use and abuse range from the local level to the global level, and insights on water management also arise from local through to global level experiences. This calls for iterative multi-level governance processes that continually progress through social learning. The article ends by calling for leadership in water governance.

The different articles in this Special Feature focus on specific research questions, and the collection of these research questions aims to present an internally consistent story. This Special Feature is based on an intensive three-day workshop that was held on October 13-15, 2010 in Bonn, Germany under the auspices of the Global Water System Project. ${ }^{[1]}$ Some of the articles were further tested at the Global Catchment Initiative Conference of the Global Water System Project in December 2010 and the European Science Foundation Conference on Water Governance in June 2011. This Special Feature contributes to the ongoing research work of the Global Water System Project and the Earth System Governance project. 
Responses to this article can be read online at: http://www.ecologyandsociety.org/issues/responses. $\mathrm{php} / 6115$

\section{Acknowledgments:}

We thank the German Federal Ministry of Education and Research for financial support for the International Project Office of the Global Water System Project organizing and supporting a workshop and the publication of this Special Feature.

\section{LITERATURE CITED}

Baumgartner, F., and C. Pahl-Wostl. 2013. UN-Water and its role in global water governance. Ecology and Society 18(3):3. http://dx.doi.org/10.5751/ES-05564-180303

Castro, J. E. 2007. Water governance in the twentieth-first century. Ambiente \& Sociedade X2:97-118. http://dx.doi. org/10.1590/S1414-753X2007000200007.

Commission on Global Governance. 1995. Our global neighbourhood: the report of the Commission on Global Governance. Oxford University Press, Oxford, UK.

Dellapenna, J., and J. Gupta. 2008. Toward global law on water. Global Governance 14(4):437-453.

Dellapenna, J., and J. Gupta, editors. 2009. The evolution of the law and politics of water. Springer Verlag, Dordrecht, The Netherlands.

Dellapenna, J., J. Gupta, L. Wenjing, and F. Schmidt. 2013. Thinking about the future of global water governance. Ecology and Society 18(3):28. http://dx.doi.org/10.5751/ES-05657-180328

Doornbos, M. 2001. 'Good governance': the rise and decline of a policy metaphor? Journal of Development Studies 37 (6):93-108. [online] URL: http://www.tandfonline.com/doi/ pdf/10.1080/713601084

Groenfeldt, D., and J. J. Schmidt. 2013. Ethics and water governance. Ecology and Society 18(1):14. http://dx.doi. org/10.5751/ES-04629-180114

Gupta, J., R. Ahlers, and L. Ahmed. 2010. The human right to water: moving toward consensus in a fragmented world. Review of European Community and International Environmental Law 19(3):294-305. http://dx.doi.org/10.1111/ j.1467-9388.2010.00688.x

Gupta, J., A. Akhmouch, W. Cosgrove, Z. Hurwitz, J. Maestu, and O. Unver. 2013. Policymakers' reflections on water governance issues. Ecology and Society 18(1):35. http://dx. doi.org/10.5751/ES-05086-180135
Gupta, J., and L. Lebel. 2010. Access and allocation in global earth system governance: water and climate change compared. INEA 10(4):377-395.

Hoekstra, A. Y. 2011. The global dimension of water governance: Why the river basin approach is no longer sufficient and why cooperative action at global level is needed. Water 3:21-46. http://dx.doi.org/10.3390/w3010021

Huitema, D., and S. Meijerink, editors. 2009. Water policy entrepreneurs: a research companion to water transitions around the globe. Edward Elgar, UK.

Kahler, M., and D. A. Lake. 2003. Globalization and governance. Pages 1-32 in M. Kahler and D. A. Lake, editors. Governance in a global economy. Princeton University Press, Princeton, USA.

Pahl-Wostl, C., K. Conca, A. Kramer, J. Maestu, and F. Schmidt. 2013. Missing links in global water governance: a processes-oriented analysis. Ecology and Society 18(2):33. http://dx.doi.org/10.5751/ES-05554-180233

Pahl-Wostl, C., J. Gupta, and D. Petry. 2008. Governance and the global water system: a theoretical exploration. Global Governance 14:419-436.

Rosenau, J. N. 1992. Governance, order, and change in world politics. Pages 1-29 in J. N. Rosenau and E. O. Czempiel, editors. Governance without government: order and change in world politics. Cambridge University Press, Cambridge, UK. http://dx.doi.org/10.1017/CBO9780511521775

Rosenau, J. N. 2000. Change, complexity, and governance in globalizing space. Pages 167-200 in J. Pierre, editor. Debating governance: authority, steering and democracy. Oxford University Press, Oxford, UK.

Schubert, S., and J. Gupta. 2013. Comparing global coordination mechanisms on energy, environment, and water. Ecology and Society 8(2):22. http://dx.doi.org/10.5751/ ES-05440-180222

${ }^{[1]}$ The Global Water System Project (http://www.gwsp.org/) is a joint project of the Global Change Programmes International Human Dimensions Programme, the International Geosphere-Biosphere Programme, DIVERSITAS, and the World Climate Research Programme. 